\title{
Belief Change: Secondary Teachers’ Class Observation
}

\author{
Siping LIU ${ }^{1, *}$, Jian WANG ${ }^{2}$ \\ ${ }^{1}$ College of Foreign Languages and Literature, Wuhan University, Wuhan, China \\ ${ }^{2}$ College of Education, Texas Tech University, U.S.A \\ *Corresponding author: siping.liu@whu.edu.cn
}

Received May 04, 2014; Revised July 02, 2014; Accepted July 07, 2014

\begin{abstract}
This essay explores the questions about preservice teachers' belief about effective teaching, especially their understanding of students, and their expectation from teacher education program. The authors ground their research in theories of teachers' belief and belief change. Data collected from 35 participants are based on openended survey questions. Findings indicate that the participants made a significant change of their belief about students after the guided observation. They believe what they need to learn from teacher education is mainly pedagogical knowledge. The authors conclude that field experience helps students make some change of their belief but they still take a rather simplistic view about teaching.
\end{abstract}

Keywords: belief, belief change, early intervention, student teacher

Cite This Article: Siping LIU, and Jian WANG, "Belief Change: Secondary Teachers' Class Observation.” American Journal of Educational Research, vol. 2, no. 7 (2014): 519-525. doi: 10.12691/education-2-7-14.

\section{Introduction}

Practicum is an important opportunity for student teachers to changes their belief system [1]. Student teachers bring with them the beliefs developed from their past experiences as students and they hold such beliefs as a filter through which they interpret the content of teacher education courses [2]. They also tend to use the information provided in teacher education courses in order to reinforce rather than challenge prior beliefs and values about teaching and learning [3]. What's more, because their beliefs are deeply entrenched, student teachers are usually resistant to change even after teacher education program [4,5]. The intention to change student teachers' belief does not necessarily mean that their beliefs are wrong. Student teachers are believed to understand classroom teaching in ways that are "scant, disorganized, and not readily related to action” [6]. Besides, student teachers are found to be overoptimistic in their belief concerning teaching multicultural students and class management [7]. In short, they are not well prepared for the complexity of classrooms characterized by the spontaneity, multidimensionality, and unpredictability [8]. Even with such a simple and overoptimistic belief, student teachers still feel reluctant to make a change.

Since teachers' beliefs play an influential role in the decisions they make in classroom teaching when they enter the profession, changing student teachers' beliefs is a task teacher educators need to handle. Empirical research finds that teachers are likely to obtain most of their teaching concepts from actual practice [9]. Such empirical preference is evident even at the preservice stage when student teachers tend to be more influenced by their cooperating teachers than by teacher education courses [10]. Under this situation early field experience may provide a more realistic view of the complexities of teaching because teaching experience plays a more decisive and formative role in shaping their beliefs [11,12] They learn more substantively in real teaching experience than in teacher education.

To change student teachers' beliefs, the priority task for teacher educators is to help student teachers develop a clear understanding of students. However, teacher education is not a food feeder, providing whatever student teachers are assumed to be short of. Actually, novice teachers will quickly realize their original beliefs are not always consistent with the real scenario as soon as they enter the profession. Based on a review of 83 studies on perceived problems facing beginning teachers, Veeman found that beginning teachers experienced a "reality shock" [[13], p. 143] when they switched from teacher education to the real classrooms for teaching. The study indentified eight perceived problems, i.e., classroom discipline, motivating students, dealing with individual differences, assessing students' work, relationships with parents, organization of class work, insufficient and/or inadequate teaching materials and supplies, and dealing with problems of individual student. Most of these problems are related to teachers' concern with students. This finding indicates that preservice teachers are not well prepared for real classroom teaching. In order to give better preparation, it is necessary for teacher educators to understand what student teachers are most concerned with and eager to learn. To address the questions of how we can change student teachers' belief and what is their perceived weakness of teacher expertise, we raise the following two questions:

1. What are the beliefs of effective teaching that student teachers hold about learners after their observation? 
2. What kind of knowledge do they expect to learn from formal teacher education?

For the first question, we focus on the influence of student teachers' observation because it is their first exposure to real teaching practice from the perspective of teaching and also because by observing how experienced teachers perform in the classroom, observers gain a better understanding of teaching practices and the teaching context [14]. However, mere observation without any guidance may not create the desired outcome. Student teachers bring to the teacher education their prior beliefs which may serve as filters through which they understand and interpret teaching activities in their own ways. Thus, unguided observation sometimes is misleading and reinforces students' conceptual stereotypes [10]. The second question addresses student teachers' expectations of teacher education and whether their expectations are consistent with the content offered in teacher education program. In short, our research questions will try to address whether student teachers will experience any change in their beliefs after supported and guided observation and whether the content provided in teacher education curriculum is consistent with their own concern.

\section{Preservice Teachers' Belief and Development}

In the literature belief has no clear-cut definitions. But researchers generally reach the consensus that belief is different from knowledge in that belief is related to evaluation and judgment while knowledge is related to objective facts [1]. Based on evaluation and judgment, beliefs may not be a true reflection of the reality. What's more, beliefs in nature are concerned with personal existential presumption and they are part of "self" identity [1]. As a result, the change of belief becomes a necessity when preservice teachers' belief system is found to be inconsistent with the real situations in the classroom. However, the attempt to change teachers' belief encounters strong resistance because the development of belief is strengthened through a process of enculturation and social construction [1]. Based on anthropological theories of cultural transmission, Van Fleet suggested that teachers' beliefs are developed through three sources: education (instruction in formal procedures), enculturation (role-learning through observation), and schooling (transmission of professional folklore which provides the unifying faith of the profession) [[15]. p. 280]. However, not all beliefs equally reject any changes. Rokeach argued that the strength of beliefs varies along a centralperipheral dimension, and the closer belief reaches the center, the harder it will resist change [16]. For preservice teachers, beliefs they hold are not materialized to such a degree that they will reject any changes. Researchers found that the beliefs that preservice teachers hold are usually rather simple and they themselves cannot articulate clearly $[17,18]$. They personally formulated a basic belief [19], a belief system that is often referred to as folk pedagogies [20], or personal history-based lay theories [21]. As a result, they simply believe that teaching is a way to transfer knowledge [22] and they attach more importance to affective variables than cognitive variables [7,23]. Because of this situation, researchers suggested that it is essential for teacher educators to help preservice teachers develop cognitive changes in the preservice period and also refine their general understanding of what teaching is [24]. Tillema introduced the 'incremental' approach which uses practical experience to "open up existing beliefs” [[25], p. 577] and through supervision and guidance, preservice teachers will eventually change their beliefs. This assumption indicates that two factors are involved in preservice teachers' belief change: practical teaching and professional guidance.

Because preservice teachers are empirically biased, and more likely to be influenced by their cooperating teachers [10], field experience rather than classroom teaching will play a more decisive role in modifying their prior beliefs. Book and Freeman argued that field experience sketches a more realistic picture of the complexities involved in teaching [26]. Studies found that preservice teachers take experience as the best teacher [27] and in field experience such as observation, preservice teachers experienced dramatic change because they interact more closely with other teachers [22]. However, because preservice teachers' beliefs act as filters and they only absorb information consistent to their belief system [28], it is necessary to intervene or guide them in order that they can observe from a professional perspective, otherwise those that are not in agreement may be left unnoticed [2].

In short, teachers' beliefs are referred to as teachers' general attitudes toward education, including schooling, teaching, learning, and students [1] and they are defined as mental constructions of experience that are held to be true, valid and credible [29,30]. To change or modify preservice teachers' beliefs according to the real situation of classrooms is to better prepare them for their future teaching and shorten the time for them to survive in the class struggling awkwardly with heavy workload and lengthened service time at school [31].

\section{Literature Review}

Contrary to the assumption that preservice teachers' beliefs are resistant to change even after formal teacher education [1], quite a number of research in the literature reported that preservice teachers did change their beliefs under certain situations where preservice teachers were exposed to real teaching practice. Tillema used four tests in the form of questionnaire to survey 36 student teachers who participated in a regularly-held seminar on teaching self-directed learning method on a regular basis [25]. The author administered the test at three-month interval. The seminar was part of course the preservice teachers were taking and it consisted of three phases: the first was three month reflection that was intended to familiarize the student teachers with the concepts of self-directed learning; the second was three-month practice teaching based on the self-directed methods; and the last was three-month supervised teaching aiming at their adoption of the selfdirected methods. By using a "factorial design with repeated measures on one factor" [[25], p. 582], the author found that a more effective way to bring about student teachers' belief change was reflection which was grounded and built upon practice teaching. 
Palmer made a similar finding when their participants were engaged in practicum. Palmer investigated preservice teachers' self-efficacy. He collected data from 55 young student teachers (20 to 25 in age) who were taking a science methods course. The data were collected from multiple sources such as one pre-test and two posttests. The instrument was called the Science Teaching Efficacy Belief Instrument. He administered the pre-test, a formal survey in the first class, and another formal survey (immediate post-rest) 13 weeks later. By the end of the course after 9 months, he conducted an informal survey. Results from ANOVA indicated a positive change that was persistent from the first post-test to the second. During the course, the student teachers also practiced teaching. Thus, the authors suggested that practicum played an effective role to reinforce the increased selfefficacy that the student teachers experienced by taking the course [32].

Based on the professional socialization approach, Lauriala grounded a similar study in student teachers' practicum settings where reformative concepts could develop student teachers' critical perspective on professional school practice. The authors collected data from 16 student teachers who participated in teaching practicum "based on the inquiry-oriented approach and the ideas of alternative pedagogies". According to interviews, student teachers' reports and narratives, the authors found that new and challenging situations in real classrooms offered an array of options and widened their viewpoints so that they could select different alternatives. The authors argued that through practicum, the student teachers began to grow out of their traditional view of teaching and began to reconstruct their own conception. The authors pointed out that because of the student teachers' close contact with children at school, they experienced a "perspective transformation". The authors finally concluded that student teachers' real change is grounded in "positive, critical, real-life experience" and they should be challenged with unfamiliar situations [[33], pp. 269-278].

As for the reasons why real teaching experience can bring the change of preservice teachers' beliefs, Beijaard and de Vries' findings may drop some hints. They interviewed six middle-aged teachers with an average teaching experience of 18 years. The interviews with these teachers were focused on questions concerning the development and change of their beliefs and factors that contributed to the change. The authors found that four patterns of belief change: 1) internally-driven and externally-stimulated change; 2) radical and gradual change; 3) individual and collaborative change; 4) change about students' learning. In general the teachers' change was primarily built on cumulative experience. The authors pointed out that dissatisfactory outcomes pushed the teachers to change accordingly because the teachers found what they did was problematic. What's more, the teachers also suffered "internal conflicts" after they reflected on their teaching, and they admitted that constant reflection effected internal changes [34].

In conclusion, it can be seen from the literature review that preservice teachers' change is based on real teaching experience. Preservice teachers' beliefs are grounded in particular situations characterized by particular events and people. Their change is based on the reflection on their experience in real classroom.
Although studies above showed that student teachers did make a change after real experience in teaching, little literature has ever touched upon the possibility that in the early stage of teacher education student teachers will change their belief and how such change will take place. To find out whether by guided observation student teachers will make some change of their belief is significant because it can quicken student teachers' change without waiting for it until after they begin to practice teaching.

\section{Methodology}

\subsection{Participants and Contexts}

This study is grounded in a teacher education program, an introductory course offered to secondary education teacher candidates in a college of education in a U.S. state university. We choose this course for our study for the following reasons. Firstly, as an entry-level course, it is the first one provided in teacher education program to students who intend to begin their professional development in secondary school teaching. As such a stage, the student teachers still stick to the prior beliefs that are formed from their experience as students [2]. Although the course only provides foundational background information about the philosophy, theories, curriculum, history, and social contexts of secondary education [35], it consists of an important and mandatory part of field experience---25-hour observation of real classes at a particular school. Students are placed to observe how a particular subject is taught by an experienced teacher and the subject is their choice of preference. Thus, this context makes it possible to examine the assumption whether the student teachers are more likely to experience a change than in the formal courses in teacher education when they are placed in real classroom situations.

Secondly, the 35 students as participants who are taking this course represent the common but also unique characters of preservice teachers. Their age ranges from 22 to 45 and most of them have no teaching experience. They decide to take the course with the intention of developing their career in the teaching profession. They also come from different backgrounds. Some have working experience in areas other than teaching. But most of them are recent graduates from high schools and hence are still fresh with their K-12 students' experience. Among the 35 participants, 30 are Whites, 2 are Hispanic and 2 are Asian Americans. Because most of them are recent high school graduates, they still wear a thick lens burnished from their experience as students to understand teaching, which, to their belief, may be "simple and straightforward activity that results in learning” [[36], p. 2]. In this sense, the role of apprenticeship of observation is stronger in influencing their beliefs about teaching [2].

It is significant for teacher education program to examine whether student teachers' belief will change or not after the completion of the course because little or no change can indicate that efforts at later stage in teacher education program to change their belief may not work either. What's more, they are also subject-oriented with a preference for a particular subject they like such as 
English language arts or mathematics. Because of their subject-centered perspective, they tend to resort to their experience as students for the understanding of professional knowledge [26]. If their beliefs about teaching are far from being adequate for real teaching [36], it is necessary to shape their prior beliefs to adjust them to the complexity of classroom teaching.

However, because the observation time is limited to only 25 hours, the participants in our study are not sufficiently exposed to real classroom teaching that may bring about substantive change in their beliefs.

\subsection{Data Collection and Analysis}

Guided by our research questions to explore the student teachers' change of belief about learners after their observation and their expectation to learn from teacher education, we asked them to focus on how their coteachers would connect their teaching with the students such as students' prior knowledge and we also asked them to examine the relationship between teaching and students' demographic composition such as their race and ethnicity. We encouraged the students to talk with their co-teacher and reflect on what they have observed. The instrument we used is questionnaire administered at the end of the course. In open-ended format, the questionnaire was designed according to a wide reading of empirical articles about teacher education and it is mainly concerned with questions about their belief on effective teaching from students' perspective and their opinions on what kind of knowledge they need to learn for effective teaching. For example, by obtaining replies from the question 'What is the most valuable experience you have gained from your observation?', we try to find out whether the participants have undergone significant change after their exposure to real class teaching.

To guarantee that the participants only focus on their new beliefs that they have developed after the observation, we made it clear at the beginning of the questionnaire that they only answer the questions if they think their answers are the result of their observation. Otherwise, just leave it blank. We then coded the participants' replies to the questionnaire to identify the participants' overall patterns of their attitude to class observation. The result from the data analysis helps to answer the two research questions.

\subsection{Limitation}

Our study first is limited in the depth of analysis. By analyzing the participants' replies to the survey questions, we can only hear part of the real story because of the complex nature of belief, which cannot be directly observed and instead it has to be inferred [16]. Thus, without direct observation of their behavior, it cannot be guaranteed that what they state in the reflections and what they select in the questionnaire is real representation of their beliefs about teaching. Besides, for survey questions, the number of participants (35 in total) is too small to generate highly significant findings that can be representative of beliefs held by secondary preservice teachers in general. Finally, because their observation is limited to 25 hours that they are supposed to complete within one semester, the time is not long enough for them to make sustainable change.

\section{Findings}

\subsection{Understanding of Students}

Based on 35 replies by the secondary student teachers, it can be found that they showed a quite clear understanding concerning how effective teaching is.

The first question in the questionnaire is concerned with the importance of understanding students' prior knowledge so that teachers can tailor their teaching accordingly. For this question, most of the students (89.6\%) gave rather similar answer: to get to know the students is the foundation of building teacher knowledge so that the teacher knows where to start. One of the students put it 'teachers should know students' level before forming their lesson because students cannot understand the curriculum if it isn't on their level."

However, the student teachers seem to be unable to find proper ways to assess students' prior knowledge. Most of them (83\%) coincidentally believed in formal assessment such as placement tests. They simply ignored what teachers could do in the classroom with informal assessment like teachers' questions and in-class quizzes, which can be used as constant check of students' knowledge and progress in order to adjust teachers' pace and revise their teaching strategies.

The student teachers held a reasonable attitude towards teaching strategies. Most of them (88\%) proposed balanced strategies between teacher-centered and students-centered approaches when they answered the following question "What teaching strategies do you prefer to implement, teacher-centered or student-centered or both?”. One of the math majors explained that studentcentered approach is more effective to customize students' acquisition of math knowledge and teacher-centered one is required to teach them the core concepts. It is interesting to note that all the student teachers whose major is language arts preferred an integration of both teachercentered and student-centered approaches while for the 7 math or science majors they split their opinions into two. Further study can be done to explore the reasons of student teachers' preference of teaching strategies from the perspective of their different majors. One of the students who chose student-centered approach based his decision on his experience and observation and he believed that it is easier to learn when one has to do it and when students help each other.

When it comes to the questions of students' individual differences, they gave quite clear and accurate judgments. Generally, their replies are divided into two parts: students' learning and environments. Answers such as learning attitudes and strength, intelligence, prior knowledge, special learning needs are concerned with students' learning. Answers like students' backgrounds such as race, socioeconomic status and culture are related to students' environments. Because the question is openended, some of the participants' replies are overlapped with both parts. However, according to the coding based on the two parts, $52 \%$ of the answers are related to the first part and $48 \%$ to the second part.

It is the same case with another question whether IQ is a decisive factor for the gap of students' performance. No participant believed that IQ decides students' performance. They attributed students' different performance to either 
learning or teaching instead of students' intelligence. One third of the respondents believed that students learn with different strategies. 9 respondents believed that students perform differently in different subjects and academic intelligence is only one indicator of their performance. Some even blamed teachers for students' poor performance. No one blamed students for their reluctance to learning.

This is also reflected in another question asking the teacher candidates to give reasons why children from lower-class families perform less well than those from middle- or upper-class. The participants' replies generally focused on three areas, namely, fewer resources, family financial pressure and less parental involvement. Based on the 41 answers coded according to the three areas, $41 \%$ is related to students' financial pressure at home. The participants explained that the children from lower-income families have to shoulder more family burden and therefore have less time left for study at home. Less parental involvement is the second reason covering about $39 \%$ of the coded answers. Some participants believed that because parents are less educated, children in such families have less pressure to push them to learn. 8\% of the answers attributed the reason to fewer and unfavorable resources available to children such as less supportive teachers or classes and bad influences in the community.

\subsection{Expectations from Teacher Education Program}

In the questionnaire one of the questions eliciting the participants' response to what they expect to learn from formal education program. The majority of them (93\%) expect to learn curricular and pedagogical knowledge from formal teacher education.

What they feel most frustrated and incompetent is class management. 9 respondents either included the word manage (management) or handle in their answers to the question of what they expect to learn in teacher education program (See Table 1). This result also echoes with responses from another question regarding the basic differences between an experienced teacher and a novice teacher. Half of the respondents distinguish a novice teacher and an experienced one by the ability of managing the classroom. One third of the teacher candidates also attribute confidence as one of the important factor that makes a difference between novice and experienced teachers. In their words, experiences are prepared for the unexpected and they feel comfortable and easy-going in well-organized classrooms. Not a single teacher candidate considers experienced teachers are better learned in subject matter knowledge or they have higher expertise for teaching.

Table 1. Student teachers' expectation to learn in teacher education program

Knowledge of pedagogy and curriculum

handle class

How to teach (strategies, classroom management, tactics)

learn about teaching

lesson plan; manage behaviors; assess

how to teach effectively; good skills; class management handle class and students

class management; plan a class schedule and lesson plan

how to teach, what to think, how to interact with students and peers

I expect to learn how to teach and become more knowledgeable with my field--English

I expect to learn how to handle teaching within the classroom

An overview of how to teach and what to prepare for

I expect to learn about how students respond to the teaching

I expect to learn about how students respond to the teaching. I want to find out how to get students to rise above their best work.

General knowledge of how to draw up plan and how to deal with diff issues

I expect detailed full knowledge of curriculum to learn so I can educate and find ways to teach. I also would like to learn technology strategies practical facts and tried practices of teaching

know what it takes to be a math teacher and diff ways on how to teach math at diff levels

Classroom management, forming lesson plan, being a "successful" teacher

Teaching and classroom management strategies

I like to learn more about my subject as well as teaching methods

\section{Discussion}

Our research questions address student teachers' belief change after their observation and their expectations from teacher education program. We restricted the participants' answers only to their new understanding of students by asking them to write about what they have learned from their observation as far as students are concerned. The findings indicate that student teacher's knowledge is prone to be affected by early field experience such as their observation of cooperating teachers [10].

In their replies, the participants showed a clear understanding why it is necessary to get to know students' prior knowledge before teaching. Tillema pointed out that student teachers' practical experience plays a decisive role to restructure their beliefs because observation presents a more realistic picture of the complexities involved in teaching [25]. By what Tillema called 'incremental' approach, student teachers "open up existing beliefs" and eventually change their beliefs that are more consistent to the real situation in the classroom [[25], p. 557]. For example, their understanding of the students turned to be more realistic.

The reason for the change in terms of their understanding of students possibly lies in Rokeach's assumption that the strength of beliefs exists in a centralperipheral dimension [16]. Their belief about students is not the fundamental knowledge that they have to hold tight and to change it will not shake the core of their belief about teaching. But according to Tillema, the change of belief is conditional to supervision and guidance that student teachers can receive [25]. Because we didn't include in our guidance regarding how to observe the assessment, the participants just ignored observing it. As a result, although the participants had a clear understanding why teachers need to know students' prior knowledge, 
most of them only could think of tests to judge it, which is most probably derived from their folk pedagogies [20].

According to central-peripheral relationship in teacher beliefs with the core beliefs being held at the center and less important ones standing on the edge [16], the core of the participants' beliefs such as their understanding of teaching remains quite stable. From their replies to the question of what they expect to learn from teacher education, most of them only believed that what they are short of is pedagogical knowledge such as classroom management. This is probably due to their former education and schooling which have gradually fostered their belief about their subject matter knowledge [15]. Brookhart \& Freeman found that in the eyes of preservice teachers, teaching is regarded a way to transfer knowledge [25]. The participants simply believe that as long as they learn how to effectively manage the classroom, they can teach successfully. By observing co-teachers' class, they gradually realize that teaching is far more complicated than simply transferring knowledge to students. Thus, they are eager to learn knowledge of pedagogy and curriculum from teacher education program. This finding confirms Hollingsworth's argument that preservice teachers need cognitive changes in the preservice period and to make such a change requires both sustainable exposure to real classroom situation and practical guidance supported by teacher educators [24].

In summary, because preservice teachers' belief system exists in central-peripheral dimension, with specific guidance early field experience such as observation in teacher education may help preservice teachers change some of their beliefs that exist around the periphery of their belief system. Previous findings about preservice teachers' change of belief were grounded in their real teaching such as practicum in the class, which means that preservice teachers only experience possible change after their completion of teacher education program [32,33]. Our findings show that preservice teachers may change their beliefs at early stage of teacher education program if they are appropriately guided in their class observation. However, further research should follow up to find out whether early field experience can fundamentally change preservice teachers' beliefs about teaching.

\section{Conclusion and Implications}

In this study, we addressed two questions about student teachers' belief change and their expectation to learn from teacher education. Student teachers hold beliefs that are ready for change. They enter teacher education program with the expectation that they can learn to be effective teachers. This indicates that their mind is open for new practical knowledge. Previous studies suggested that preservice teachers went through teacher education without much change of their belief. Our study shows that change depends on intervention, which stimulates student teachers' consciousness to restructure their existent stigmata. For teacher educators, the questions are not whether we should reform teacher education or not but to make a better use of it so that its potential resources can be exhausted. Effective intervention is proactive, which means that teacher educators cannot wait for changes to occur. Instead, they should use each course, workshop or student teaching activity to guide student teachers in their belief change.

\section{Acknowledgement}

The paper is part of the research for the "2014 Social Science Research Grant of Hubei Province”, China.

\section{References}

[1] Pajares, M. F. "Teachers' Beliefs and Educational Research: Cleaning Up a Messy Construct”, Review of Educational Research, 62 (3), 307-332. 1992.

[2] Lortie, D.C. Schoolteacher. Chicago: University of Chicago Press. 1975.

[3] Kagan, D. "Professional Growth among Preservice and Beginning Teachers”, Review of Educational Research, 62 (2), 129-69. 1992.

[4] Mattheoudakis, M. "Tracking Changes in Pre-Service EFL Teacher Beliefs in Greece: A Longitudinal Study”, Teaching and Teacher Education: An International Journal of Research and Studies, 23 (8), 1272-1288. 2007.

[5] Feiman-Nemser, S. and Buchman, M. When is student teaching teacher education? East Lansing, Mich.: The Institute for Research on Teaching, College of Education, Michigan State University. 1986.

[6] Calderhead, J., and Robson, M. "Images of teaching: Student teachers' early conceptions of classroom practice”, Teaching and Teacher Education, 7 (1), 1-8. 1991.

[7] Weinstein, C. S. "Preservice teachers' expectations about the first year of teaching”, Teaching and Teacher Education, 4 (1), 31-40. 1988.

[8] Doyle, W. "Learning the classroom environment: An ecological analysis”, Journal of Teacher Education, 28 (6), 51-55. 1977.

[9] Zahorik J.A. "Teachers' collegial interaction: An exploratory study”, The Elementary School Journal, 87 (4), 385-396. 1987.

[10] Calderhead, J. "Knowledge structures in learning to teach", in Calderhead, J. (Ed.) Teachers' professional learning. London: Falmer Press. 51-64. 1988.

[11] Shulman, L. "Those who understand: A conception of teacher knowledge”, American Educator, 10 (1), 9-15, 43-44. 1986.

[12] Shulman, L. "Knowledge and teaching: Foundations of the new reform”, Harvard Educational Review, 57 (1), 1-22. 1987.

[13] Veeman S. "Perceived problems of beginning teachers", Review of Educational Research, 54 (2), 143-178. 1984.

[14] Bogdan, R. C., and Biklen, S. K. Qualitative research for education: An introduction to theory and methods (2nd Ed.). Needham Heights, MA: Ally and Bacon. 1992.

[15] Van Fleet, A. "Learning to teach: The cultural transmission analogy", Journal of Thought, 14 (4), 281-290. 1979.

[16] Rokeach, M. Beliefs, attitudes, and values: A theory of organization and change. San Francisco: Jossey-Bass. 1968.

[17] Clark, C. M. "Asking the right questions about teacher preparation: Contributions of research on teaching thinking”, Educational Researcher, 17 (2), 5-12. 1988.

[18] Nespor, J. "The role of beliefs in the practice of teaching”, Journal of Curriculum Studies, 19 (4), 317-328. 1987.

[19] Buchmann, M., and Schwille, J. "Education: The overcoming of experience”, American Journal of Education, 92 (1), 30-51. 1983.

[20] Bruner, J. "Frames for thinking: Ways of making meaning”, in D. R. Olson and N. Torrance (Eds.), Modes of thought: Explorations in culture and cognition. New York: Cambridge University Press. 93-105. 1996

[21] Holt-Reynolds, D. "Personal history-based beliefs as relevant prior knowledge in course work", American Educational Research Journal, 29 (2), 325-349. 1992.

[22] Brookhart, S. M., and Freeman, D. J. "Characteristics of entering teacher candidates”, Review of Educational Research, 62 (1), 3760. 1992.

[23] Porter, A. C., and Freeman, D. J. "Professional orientations: An essential domain for teacher testing”, Journal of Negro Education, 55 (3), 284-292. 1986. 
[24] Hollingsworth, S. "Prior beliefs and cognitive change in learning to teach", American Educational Research Journal, 26 (2), 160189. 1989.

[25] Tillema, H. "Belief change towards self-directed learning in student teachers: Immersion in practice or reflection on action", Teaching and Teacher Education, 16 (5-6), 575-591. 2000.

[26] Book, C. L. and Freeman, D. J. "Differences in entry characteristics of elementary and secondary teacher candidates”, Journal of Teacher Education, 37 (2), 47-51. 1986.

[27] Book, C. L., Byers, J., \& Freeman, D. J. "Student expectations and teacher education traditions with which we can and cannot live", Journal of Teacher Education, 34 (1), 9-13. 1983.

[28] Zeichner, K. M., and Tabachnick, B. R. "Are the effects of university teacher education 'washed out' by school experience?", Journal of Teacher Education, 32 (1), 7-10. 1981.

[29] Sigel, I. E. "A conceptual analysis of beliefs", in I. E. Sigel (Ed.), Parental belief systems: The psychological consequences for children. Hillsdale, NJ: Erlbaum. 345-371. 1985.

[30] Harvey, O. J. "Belief systems and attitudes toward the death penalty and other punishments”, Journal of Personality, 54 (4), 659-675. 1986.
[31] Glickman, C. D. Supervision of Instruction: A Developmental Approach. Boston: Allyn and Bacon, Inc. 1985.

[32] Palmer, D. "Durability of changes in self-efficacy of preservice primary teachers", International Journal of Science Education, 28 (6), 655-671. 2006.

[33] Lauriala, A. "The Role of Practicum Contexts in Enhancing Change in Student Teachers' Professional Beliefs”, European Journal of Teacher Education, 20 (3), 267-282. 1997.

[34] Beijaard, D., and de Vries, Y. "Building expertise: A process perspective on the development or change of teachers' beliefs", European Journal of Teacher Education, 20 (3), 243-55. 1997.

[35] Hall, G. E., Quinn, L.F. and Gollnick, D. M. The joy of teaching: Making a difference in student learning. Boston, MA: Pearson Education, Inc. 2008.

[36] Feiman-Nemser, S., McDiarmid, W. G., Melnick, S.L., and Parkea M. "Changing beginning teachers' conceptions: A description of an introductory teacher education course". Paper presented at American Educational Research Association, Washington, DC. 1989. 